\title{
PRZECIW „IDEOLOGIOM”. „WOLNOŚĆ” NAUKI \\ JAKO STAWKA W WOJNACH KULTUROWYCH
}

\section{Marta Zimniak-Hałajko*}

Abstrakt

Przedmiotem analizy w niniejszym tekście są wybrane działania instytucjonalne i akcje społeczne, podejmowane w latach 2018-2020 w Polsce na uczelniach i poza nimi, mające na celu ustalenie, co i komu można mówić w ramach akademii oraz co może mówić uczony zabierający głos w debacie publicznej. Wybrane inicjatywy społeczne i ustawodawcze na gruncie polskim omówione zostają w szerszym kontekście: aktywności ruchów społecznych o wyraźnym obliczu ideowym (lewicowych i prawicowych), sprzeciwów wobec organizowania na uczelniach wykładów i debat o charakterze uznanym za „ideologiczny”, inicjatyw na rzecz wolności debaty na uczelniach.

Słowa kluczowe: uniwersytet, wolność słowa, wolność akademicka, ideologia, ruchy spoteczne, konflikt, debata publiczna

\section{AGAINST „IDEOLOGIES”. „FREEDOM” OF SCIENCE AT STAKE IN CULTURE WARS}

Abstract

The subject of the current article is the analysis of select institutional activities, including drafts of legislative initiatives and social actions, that took place during 2018-2020 at Polish universities (and outside of them), aiming at defining of what can be expressed, who is entitled to speak within the realm of academy - and what can be said by an academic teacher or scientist during public debate. These social actions and legislative initiatives are discussed in the broader context of activities of social movements having clear ideological face (either left- or rightwing), protests against lectures and debates organised at universities that were labelled as „ideological” ones, as well as projects intending to promote specific visions of academic freedom along with corresponding regulations for universities.

Keywords: university, freedom of speech, academic freedom, ideology, social movements, conflict, public debate

\footnotetext{
*Dr hab. Marta Zimniak-Hałajko, Uniwersytet Warszawski

e-mail: m.zimniak@uw.edu.pl |ORCID: https://orcid.org/ 0000-0002-4081-6579
} 
Przedmiotem analizy w niniejszym tekście będą wybrane działania instytucjonalne i akcje społeczne, podejmowane w ostatnim czasie (w latach 2018-2020) w Polsce na uczelniach i poza nimi, mające na celu ustalenie, co (i komu) można mówić w ramach akademii oraz co może mówić uczony zabierający głos w debacie publicznej.

Wybrane akcje na gruncie polskim - działania związane z postępowaniem dyscyplinarnym wobec prof. Aleksandra Nalaskowskiego i prof. Ewy Budzyńskiej oraz projektem nowelizacji ustawy Prawo o szkolnictwie wyższym i nauce - omawiać będę w szerszym kontekście: aktywności ruchów społecznych o wyraźnym obliczu ideowym (lewicowych i prawicowych), sprzeciwów wobec organizowania na uczelniach wykładów i debat o charakterze uznanym za ,ideologiczny”, inicjatyw na rzecz wolności debaty na uczelniach (również w innych krajach). J ednemu z tych kontekstów - praktykom zakłócania wykładów przez przeciwników ich tematyki lub osoby prelegenta - poświęciłam osobny artykuł (ZimniakHałajko 2019), w związku z tym nie będę go tu przywoływać.

Prezentacja szerszego tła aktualnych dyskusji o wolności akademickiej służy moim zdaniem lepszemu zrozumieniu miejsca akademii w wojnach kulturowych i powiązanych z nimi sferach debaty publicznej. Nie jest bowiem tak, że akademia może unikać uczestnictwa w wojnach kulturowych. Uczestnictwo to jest w dużej mierze nieuchronne, także w formie obrony wartości czy bezstronności: dotychczasowe praktyki w tym względzie są już po części skonwencjonalizowane, lecz nieskodyfikowane. W artykule niniejszym chciałabym zastanowić się, czy warto te praktyki instytucjonalizować i wjaki sposób można to uczynić.

Wojny kulturowe rozumiem tu, za Wojciechem Bursztą (2013), jako taki typ konfliktu normatywnego w społeczeństwie posttradycyjnym, który przebiega między konserwatystami („fundamentalistami”, „prawicą”) a liberałami („relatywistami”, „lewicą”) i przybiera postać sporu moralnego, pojmowanego przez strony w kategoriach walki Dobra ze Złem, a zatem prowadzącego do ponawianych przez przez nie prób eliminacji wrogich im idei z przestrzeni publicznej i życia społecznego. 
W tekście niniejszym nie ma niestety miejsca na szczegółową rekonstrukcję dynamiki wojen kulturowych w Polsce oraz ich instytucjonalnego i organizacyjnego zaplecza (w tym na próby precyzyjnego zdefiniowania „prawicy” i „lewicy”: tu polegać będę na samookreśleniach aktorów i ich pozycjonowaniu się w polu wojen kulturowych). Warto jednak odnotować, że w roku 2013 wojny kulturowe wchodzą w nową fazę w związku z mobilizacją ideową i organizacyjną konserwatystów. Nasila się walka z „ideologią gender”, definiowaną przez prawicę jako narzędzie dekonstrukcji tradycyjnych tożsamości i więzi społecznych (analiza medialnego konfliktu o gender por. Duda 2016). „Ideologia gender" funkcjonuje w światopoglądzie prawicowym jako synekdocha: zawiera w sobie wszelkie destabilizujące tradycyjny ład zjawiska: „ideologię LGBT” i queer, „neomarksizm”, „multikulturalizm”.

W roku 2013 powstaje również sieć europejskich organizacji konserwatywnych Agenda Europe (por. agendaeurope.wordpress.com), stawiająca sobie za cel aktywne przywracanie konserwatywnego ładu wEuropie, oraz jej polska instytucja partnerska - Instytut na rzecz Kultury Prawnej Ordo Iuris. Ta ostatnia jest jedną z głównych bohaterek niniejszego tekstu.

Proponowana tu analiza to kulturoznawcze studium wybranych przypadków ramowania sporów w przestrzeni medialnej. W każdym z nich starałam się dotrzeć do upublicznianych w mediach (internecie, czasopismach, w przypadku prof. Nalaskowskiego - również książce) tekstów i oświadczeń, konstytutywnych dla ram sporu, zamieszczanych przez samych zainteresowanych lub instytucje działające wich imieniu, a także innych aktorów uczestniczących w konflikcie bezpośrednio (studenci, instytucje szkolnictwa wyższego).

Nie było więc moim celem prześledzenie wszystkich materiałów medialnych związanych z opisywanymi przypadkami ani też próba dotarcia do istotnych aktorów w celu weryfikacji ich opinii i kontekstów zdarzeń. Obraz medialny wydaje mi się tu ważniejszy od „faktów”, a te ostatnie- praktycznie niemożliwe do zrekonstruowania w obliczu emocji 
wywołanych sporami, a także strategii budowania (przez osoby lub instytucje) swej obecności w przestrzeni informacyjnej.

Niniejszy tekst wpisuje się w ustabilizowanyjuż nurt refleksji o wolności akademickiej, której istota rozważana jest wciąż na nowo w kontekście kolejnych wydarzeń czy incydentów, zazwyczaj mających związek z konfliktami kulturowymi i politycznymi (por. np. Fish 2014, 2019; Nelson 2010; Wallach Scott 2019; Academic Freedom in the Post-9/11 Era 2010; Who's afraid of academic freedom? 2015). Nurt ten Stanley Fish określa jako academic freedom studies (2014: 7).

Pluralizm debaty czy akademia wolna od tego, co nienaukowe?

Opisywane w tym podrozdziale przypadki postępowania dyscyplinarnego prowadzonego na uczelniach wobec zatrudnionych w nich naukowców są - w momencie, gdy piszę te słowa (sierpień 2020) - wciąż niezakończone. Trwają jednak wystarczająco długo, by próbować wydobyć interesujące prawidłowości. W obu przypadkach profesorowie z dużym stażem dydaktycznym i naukowym zostali oskarżeni o nadużycie praw wolności uypowiedzi: prof. Ewa Budzyńska podczas prowadzonego przez siebie wykładu, prof. Aleksander Nalaskowski w felietonie opublikowanym w prawicowej prasie.

Zarzut nienaukowości i ideologiczności wywodu postawiony został tylko w wypadku wykładu, ale oczywiście już nie felietonu; obojgu akademikom zarzucono użycie niestosownych słów, „krzywdzącej mowy” skierowanej przeciw określonym grupom osób (o pojęciu „krzywdzącej mowy": Butler 2010). Oskarżający utrzymywali, że rola nauczyciela akademickiego nie zezwala na ten typ wypowiedzi: nie tylko w murach akademii, ale i poza nią. Oskarżeni konsekwentnie twierdzili, że ich wypowiedzi były zgodne z konwencją gatunkową (wykład, felieton) i realizując je wypelniali misję wpisaną w rolę społeczną akademika. Działania oskarżających uznali za motywowany poprawnością polityczną i ideologią 
lewicową zamach na wolność słowa, próbę cenzury i wyciszenia: nieprawomyślnych zdaniem skarżących opinii, w tym aprobaty dla tradycyjnych wartości i norm.

Oba przypadki postępowań dyscyplinarnych, od początku toczących się w kontekście wojen kulturowych, stały się pretekstem do podjęcia co jakiś czas wznawianej debaty o granicach wolności słowa na uczelniach oraz miejscu ideologii w dyskusjach prowadzonych wramach akademii. W opisywane postępowania dyscyplinarne, formalnie toczące się wewnątrz uczelni, niezależnie od władz rektorskich, nacisków zewnętrznych i organów politycznych, zaangażowane były na różnych etapach organizacje pozauczelniane, decydenci polityczni oraz media. Wysunięto zarzuty wobec świata nauki i szkół wyższych (zwłaszcza w konserwatywnych i prawicowych mediach), twierdząc, że uczelnie ulegają ideologicznym modom i naciskom, stosując cenzurę wobec niezgodnych z owymi modami badań i wypowiedzi.

W ten sposób stawką w grze stała się niezależność akademii: skoro bowiem świat nauki nie potrafi sam obronić się przed ideologicznymi zakusami, być może potrzebujeinstancji zewnętrznej, która pomożemu w definiowaniu i przestrzeganiu zasad niezależności? W debacie publicznej powrócił dobrze ugruntowany w niej argument z czasów poprzedzających reformę szkolnictwa wyższego: akademia ma się źle (dowodem są jak zawsze niskie pozycje polskich uczelni w rankingach światowych, nawet wtedy, gdy zarzuty dotyczą niemierzonych wrankingach wskaźników¹), może być naprawiona tylko przez siły zewnętrzne, za pomocą odpowiednio skonstruowanego prawa.

Wykład profesor Ewy Budzyńskiej

Sprawa Ewy Budzyńskiej (ze względu na niejawność dokumentacji sporządzonej w postępowaniu wyjaśniającym i dyscyplinarnym na Uniwersytecie Śląskim) dostępna jest jedynie poprzez relacje zwaśnionych

' Przykład tego typu argumentacji przytaczam w drugiej części artykułu. 
stron, organizacji udzielających im poparcia oraz mediów sympatyzujących zazwyczaj z jedną ze stron. W czasie reakcji (najczęściej emocjonalnej) zdarzenia ulegają reinterpretacji, a stanowiska radykalizacji.

W grudniu 2018 roku dr hab., prof. UŚ Ewa Budzyńska prowadziła w ramach zajęć fakultatywnych „Międzypokoleniowe więzi w rodzinach światowych" wykład dotyczący modelu rodziny chrześcijańskiej, ze szczególnym uwzględnieniem katolicyzmu (modele rodziny w innych religiach omawiane były na wykładach wcześniejszych). Wiadomo, że na wykładzie profesor poruszała takie zagadnienia jak funkcja małżeństwa, antykoncepcja, aborcja, fazy rozwoju prenatalnego, wychowanie dzieci w rodzinach nieheteronormatywnych i opieka żłobkowa. Relacje stron - studentów, którzy złożyli skargę na prof. Budzyńską oraz samej profesor - na temat sposobu ujęcia treści są różne. Sformułowana bezpośrednio opinia studentów, która dotarła do mnie przez anglojęzyczny newsletter organizacji badawczej Atgender (widać więc, że sprawa nabrała ponadlokalnego rozglosu) i została opublikowana na stronie internetowej Kampanii Przeciw Homofobii, zawierała między innymi takie stwierdzenia:

„W 2018 mieliśmy zajęcia z wykładowczynią, która przekonywała nas na zajęciach, że aborcja to morderstwo, stygmatyzowała różne grupy wyznaniowe, mówiła nieprawdę o dzieciach z tęczowych rodzin. Na jej wykładach usłyszeliśmy, że muzułmanie przyjeżdżają do Europy, żeby gwałcić, a gazety powinny podawać wyznanie gwałcicieli, aby ludzie zobaczyli, że gwałcą głównie muzułmanie. Na jej zajęciach przedstawiano nam również fałszywe informacje na temat antykoncepcji - wykładowCzyni mówiła, że stosowanie wkładki domacicznej prowadzi do comiesięcznej aborcji, a dzieci kobiet stosujących wkładkę urodzą się z antenkami w głowach. Dr hab. Budzyńska stawiała znak równości pomiędzy antykoncepcją awaryjną i środkami poronnymi. Przekazywała nam również treści homofobiczne, twierdząc, że dzieci wychowywane przez osoby tej samej płci zawsze są nieszczęśliwe. Ostrzegała również chłopców, żeby nie „pożyczali spermy” lesbijkom. A to tylko niektóre absurdy, jakie 
usłyszeliśmy na zajęciach. (...) Uniwersytety muszą pozostać wolne od uprzedzeń, a wykładowcy, którzy zamiast wiedzy naukowej przekazują studentom i studentkom swoje poglądy i uprawiają ideologię, powinni zaprzestać tych praktyk. Przekaz oparty na dezinformacji i zaprzeczaniu wiedzy naukowej nie powinien mieć miejsca w murach uniwersytetów. Chcemy uniwersytetów wolnych od nienawiści. Chcemy wiedzy i nauki, nie uwsteczniających ideologii!"(Oświadczenie studentów/ek Uniwersytetu Śląskiego: Chcemy Uniwersytetu wolnego od nienawiści! 2020)

Prócz przekazu wiedzy niezgodnej ze stanem badań studenci zarzucili wykładowczymi homofobię, nietolerancję i próbę narzucenia poglądów katolicko-radykalnych. W wywiadzie udzielonym OKO.press twierdzili, że wykładowczyni prezentowała głównie swoje poglądy i filmy z TV Trwam, nie aktualny stan badań (Leszczyński 2020²). Budzyńska nie zgodziła się z żadnym z zarzutów, twierdząc, że jedynie przekazywała wiedzę, nie stygmatyzując w żaden sposób grup społecznych i wyborów życiowych:

„Nie narzucam, lecz prezentuję, informuję. Informacja o etapach rozwoju dziecka jest przecież przekazywaniem obiektywnych, naukowych treści, w dodatku obecnych w programach nauczania od klasy 4. szkoły podstawowej. (...) Mówienie dziś o rodzinie pełnej, małżeńskiej, trwałej, w której rodzą się dzieci, posiadającej liczne powiązania krewniacze, odbierane jest jako stygmatyzowanie. Za chwilę pedagog nie będzie już mógł prowadzić wykładu na temat rodziny pełnej, trwałej i szczęśliwej jako najlepszego środowiska dla wychowania dziecka, gdyż zostanie oskarżony o stygmatyzowanie osób tworzących inne związki" (cytat za: Grajewski 2020).

Pytana w wywiadzie, czy rozważyłaby korektę programu swoich zajęć, nie widzi potrzeby zmian:

\footnotetext{
${ }^{2}$ Warto odnotować, że artykuł Adama Leszczyńskiego jest krytyczny nie tylko w ocenie jakości dydaktyki Budzyńskiej (tu autor polega na swoich rozmówcach - studentach), lecz i jej dorobku naukowego. Klasyczna socjologia Budzyńskiej, której konserwatyzm polega przede wszystkim na wyborze i ujęciu tematów, nie zaś manifestowaniu konserwatywnych poglądów, ma również i pozytywne recenzje (por. Kwak 2018).
} 
„Nie zmieniłabym niczego w moim wykładzie także dlatego, że realizując prawo do wolności akademickiej, przekazuję wiedzę o najbardziej podstawowych wartościach, jak rodzina i prawo do życia. Z wywodu rzecznika dyscyplinarnego jednak wnoszę, że uczelnia powinna sporządzić spis treści zakazanych do nauczania w przestrzeni uniwersyteckiej" (Ibidem).

W tym samym wywiadzie Budzyńska wskazuje na podobieństwo losów swoich i swego ojca, który został zmuszony do przejścia na wcześniejszą emeryturę wskutek donosu zetempowskiego kolektywu ${ }^{3}$. Podkreślając brak wsparcia ze strony uczelni, informuje o wsparciu pochodzącym z zewnątrz akademii i jego charakterze:

„Dużo e-maili ze słowami wsparcia i solidarności, także zapewnienia o modlitwie, przychodzi na adres uniwersytecki. W części z nich pojawiają się relacje, że już wcześniej na uczelni zdarzały się takie zjawiska jak propagowanieideologii gender czy otwarte prezentowanie się niektórych wykładowców podczas zajęć jako osoby homoseksualne, ale nikt nie miał odwagi na to reagować. Obawiano się problemów z zaliczeniem egzaminu bądź ośmieszenia czy piętnowania na forum grupy przez wykładowcówlub zwolenników tamtych poglądów. To zaś oznacza, że element lęku, aby nie wychylać się, aby nie ujawniać własnych poglądów, już jest obecny w społeczeństwie" (Ibidem).

Rekonstrukcja zdarzeń na podstawie relacji stron jest zawsze hipotetyczna, można domyślać się jednak ich możliwego przebiegu. Wykładowczyni prowadziła zajęcia fakultatywne na temat ściśle związany zjej specjalizacją i publikacjami, wykorzystywała więc zapewne materiały zebrane w trakcie badań. Ponieważ czuła się pewnie w temacie, mogła w jakiejś mierze polegać na improwizacji i robić dygresje (na to wskazują przytoczone w wywiadzie dla OKO.press wypowiedzi studentów). Można domniemywać - takie ćwiczenie myślowe uważam za pożyteczne ze względu na rozważenieinnego możliwego sposobu ramowania zdarzeń, choć nie jest ono ugruntowane w zebranych materiałach - że

3 W listopadzie 2019 roku prof. Budzyńska rozwiązała umowę z uniwersytetem za porozumieniem stron i przeszła na emeryturę. 
omawiając niektóre ważne jej zdaniem zagadnienia przyjmowała rolę wychowawcy i próbowała kształtować postawy zgodnie ze swym rozumieniem etosu akademickiego i prawa do interpretacji. W prezentacji tego, co uznała za fakty, kierowała się klasyczną korespondencyjną definicją prawdy; zapewne przywoływała badania, które wybrane fakty potwierdzają (wobec braku danych trudno wyrokować o jakości tych badań).

Zarzuty studentów wydają się odnosić właśnie do tych części wykładów, które nie mieściły się w scenariuszu zajęć, domyślnie zakładającym zgodność z sylabusem (kontraktem) i neutralność światopoglądową wykładowcy (ewentualnie: prezentowanie swoich opinii jako jednych z możliwych). Taki opis konfliktu pozwalałby wskazać jako jego możliwą przyczynę błędy metodyczne wykładowczyni: akademiczka z dużym stażem nie dostosowała dynamiki zajęć do zmieniających się oczekiwań studentów (brak tolerancji dla improwizacji, dygresji, prezentacji osobowości i światopoglądu wykładowcy, przyjmowania przez niego ról wychowawczych).

Przyjęcie takiego rozumienia konfliktu otwierałoby drogę mediacji. Owocem skutecznej mediacji mogłaby być korekta sylabusa, scenariusza zajęć i sposobu prezentacji zagadnień (jednak nie zupełna zmiana sylabusa czy konieczność ukrywania poglądów przez wykładowczynię). Korekta taka mogłaby sprawić, że wykładowczyni pełniej zrealizowałaby swoje cele dydaktyczne, jednak ustalenie, że warto ją przeprowadzić, wymagałoby zawieszenia przywilejów związanych ze specyficzną formą akademickiego autorytetu pedagogicznego (zasada niezależności w tworzeniu programów i niepodważania wartości merytorycznej i metodycznej zajęć, wyrażająca się miedzy innymi w niechęci do wprowadzania zasad peer review w dydaktyce). W pewnym sensie być może łatwiej więc było doświadczonej wykładowczyni przyjąć ideologiczną ramę konfliktu i pozycjonować się w ramach opozycji prawda/ fałsz, do- 
bro/ zło, niezależność/ideologia, niż ramę dydaktycznego niepowodzenia, wymagającą myślenia o zajęciach w kategoriach skuteczności/ nieskuteczności.

Konflikt światopoglądowy, wywołany poruszaniem na zajęciach kwestii z repertuaru wojen kulturowych, utrwalił się więc jako jedyna ramainterpretacyjna spornej sytuacji. Materiały związanez postępowaniem wyjaśniającym i dyscyplinarnym są niejawne, można jednak sądzić, że w toku postępowania wyjaśniającego doszło do samoutwierdzenia się stron w przyjętej ramie, co uniemożliwiło skuteczną mediację i zaowocowało wnioskiem rzecznika dyscyplinarnego Uniwersytetu Śląskiego o karę nagany dla dr hab. Ewy Budzyńskiej, uzasadnianym narzucaniem przez wykładowczynię światopoglądu o charakterze wartościującym i manifestowaniem nietolerancji, motywowanym koniecznością podjęcia działań prewencyjnych (fragmenty zuzasadnienia, które cytuje prasa).

Decydujące dla wzmocnienia ramy światopoglądowej konfliktu oraz jego nasilenia było zaangażowanie przez prof. Budzyńską w charakterze swych obrońców prawników z Instytutu na rzecz Kultury Prawnej Ordo Iuris, jednej z najaktywniejszych w Polsce organizacji działających na polu wojen kulturowych po stronie prawicowej. Instytut nagłośnił sprawę w swym newsletterze, na stronie internetowej oraz w mediach, uruchomił też petycję w obronie wykładowczyni, pod którą podpisało się ponad 38000 osób. W treści petycji, pod symboliczną ilustracją, przedstawiającą drobną kobietę, odpychającą wymierzoną w nią olbrzymią pięść na tle tęczowej flagi, przeczytać można między innymi:

„Wszystko wskazuje, że oskarżenia wobec prof. Budzyńskiej stanowią część kampanii zastraszania wykładowców uniwersyteckich, którzy ośmielają się stawać w obronie rodziny i podejmują polemikę z postulatami ideologii gender i organizacji LGBTQ.

Za tzw. homofobię uznano posługiwanie się definicją małżeństwa spójną z polską konstytucją tj. jako związku mężczyzny i kobiety, a także prezentację wynikówbadań naukowych potwierdzających negatywneskutki 
wychowywania dzieci przez pary osób tej samej płci. (...) Uniwersytet Śląski powinien być ostoją wolności słowa i swobody prowadzenia badań naukowych oraz przykładem stosowania jednakowych standardówi wymogów etycznych wobec wszystkich członków społeczności akademickiej, a nie trybuną propagandową agresywnych grup lobbystycznych czy ideologii uderzających w małżeństwo i rodzinę!" (Brońmy Profesor! 2020)

Ordo Iuris reprezentuje Ewę Budzyńską zarówno w postępowaniu dyscyplinarnym, jak i postępowaniu prokuratury, które wszczęte zostało wskutek doniesienia o możliwości popełnienia przestępstwa z art. 235 kodeksu karnego (tworzenia fałszywych dowodów skutkujących ściganiem)4 ${ }^{4}$ Przez prawników Instytutu prof. Budzyńska ukazywana jest jako pokrzywdzona: szczególnie przez nierzetelnie ich zdaniem prowadzone postępowanie wyjaśniające i dyscyplinarne. W postępowaniu prokuratorskim przesłuchiwani byli w obecności prawników Ordo Iuris studenci (w dyskursie prawicowym przedstawiani najczęściej jako ofiary lewicowej ideologii) - liczne środowiska naukowe opublikowały protesty w tej sprawie, zarzucając Instytutowi próbę ich zastraszenia.

W lipcu 2020 roku prokuratura umorzyła postępowanie - na tę decyzję Instytut złożył zażalenie. W czerwcu oskarżany przez Ordo Iuris rzecznik dyscyplinarny UŚ zagroził Ordo Iuris pozwem i zażądał usunięcia informacji o sprawie ze stron Instytutu. O nieingerowanie w postępowanie toczące się na uczelni, zaprzestanie dezinformacji oraz nieantagonizowanie środowiska akademickiego apelował rektor UŚ i pracownicy Wydziału Prawa i Administracji UŚ.

Sprawa zaczęła jednak żyć własnym medialnym życiem. Na podstawie fragmentarycznych informacji uzyskanych od stron prawicowe i liberalne media przedstawiały własne osądy zdarzeń. J ednocześnie interpretacje w coraz mniejszym stopniu odnosiły się do sprawy, a w coraz większym do przyjętej ramy światopoglądowej. W oczach prawicy sprawa

\footnotetext{
4 Postępowanie zostało wszczęte na podstawie doniesienia o podejrzeniu popetnienia przestępstwa w postępowaniu dyscyplinarnym, złożonego przez działaczkę Solidarnej Polski z województwa śląskiego.
} 
prof. Budzyńskiej to kolejna potyczka z „ideologią gender i LGBT”, walka z „neomarksizmem” i poprawnością polityczną w życiu społecznym. Wolność od dominacji ideologii, obrona wolności akademickiej oraz obrona rodziny i tradycji tworzą tu kontinuum. Pojawiająca się nieciągłość między żądaniem pluralizmu i swobody interpretacji a postulatami usunięcia „ideologii gender” i „lobby LGBT” z akademii nie jest szczegółowo problematyzowana. Żądanie uwolnienia akademii od gender i marksizmu przedstawiane jest jako rugowanie tego, co „nienaukowe”. Wprawdzie ideologie religijne również naukowe nie są, ale można bronić ich obecności na uczelniach inaczej: odwołując się do ładu naturalnego (esencjalnej prawdy) i tradycji ugruntowanej wkonstytucji (porządku prawnego).

Przedstawiciele nauki, co ciekawe, na użytek debaty publicznej posługują się również definicją prawdy zbliżoną do klasycznej (nauka oparta na badaniach i dowodach, także w naukach społecznych) i performatywnej (wyrażanie aprobaty dla sądów), podczas gdy wewnątrz akademii korzystają częściej - zwłaszcza w naukach humanistycznych i społecznych - z teorii epistemicznych, hermeneutycznych, komunikacyjnych, pozwalających ukazać złożoność zjawisk i procesówich poznania.

J ak zauważa Harry Collins (2018), to, co wewnątrz nauki jest debatą wokół wątpliwości, na zewnątrz świata nauki reprezentowane jest jako zbiór spolaryzowanych pewników, wokół których toczy się batalie. Pojęcie „prawdy”, w tym „naukowej”, nie może być więc gruntem, na którym spotkają się światopoglądy, ponieważ pojęcie prawdy występuje zawsze w „pakiecie ontologicznym” (Ziemińska 2013) z innymi pojęciami (faktu, sądu, odniesienia) i określoną wizją świata. Dlatego też postulat zawarty w petycji wykładowców Uniwersytetu Śląskiego, solidaryzujących się z przesłuchiwanymi studentami, by w świecie akademii odróżniać „wiedzę, opinię i dogmat” oraz respektować zasady „konsensusu naukowego" - okazuje się w praktyce trudny do realizacji (Solidarnie z przestuchiwanymi studentkami i studentami Uniwersytetu Ślaskiego 2020). 
Pojęcie prawdy naukowej, używane w dyskursie publicznym, można uznać za rodzaj retorycznej fikcji. Ustalenia naukowe są zawsze osadzone w kontekście społecznym - nie istnieją wyraźne granice między światem społecznym a światem nauki. Przeprowadza się oczywiście przekonujące próby oddzielenia ekspertów od nie-ekspertów, trudniej jednak jednoznacznie określić, jakie stanowiska są najbliższe „prawdy” wewnątrz samej akademii (Collins 2018; Fish 2016).

Naukowcy stanowią grupę społeczną, która - podobnie jak inne grupy, w tym eksperckie - podatna jest na wpływy myślenia grupowego, a więc odrzucania, w imię jedności i harmonii, możliwości rozważenia innych perspektyw; przyczyną poddania się myśleniu grupowemu może być konformizm, moda na określone ujęcia, zasobochłonność związana ze zmiana perspektywy, interes grupowy czy walka o pozycję (Groupthink in Science. Greed, Pathological Altruism, Ideology, Competition, and Culture 2020).

Powodem niepodejmowania określonych tematów w badaniach i dydaktyce bywa chęć uniknięcia kontrowersji (Cole 2015). Nauka związaną jest ze społecznymi wyobrażeniami swych czasów, społecznymi stosunkami władzy i szeroko rozumianymi ideologiami. Pojęcie ideologii, jak słusznie zauważa Krzysztof Świrek (2013), używane jest dziś w analizach niechętnie poprzez skojarzenia z totalitaryzmami czy doktrynami parareligijnymi - chętniej mówi się o dyskursie, ponieważ pojęcie to pozwala na ukazanie związków porządków epistemologicznych z systemami władzy. Inną przyczyną niechęci do tego pojęcia może być, jak twierdzi Pietro Daniel Omodeo (2019), negacja przez ideologię swego ideologicznego charakteru (tu autor powołuje się na tezy Louisa Althussera) lub dążenie do przezroczystości ideologii, która powinna być odbierana jako neutralna (takie ujęcie ideologii wywodzi się zdaniem Omodeo z pism Antonia Gramsci'ego).

W literaturze przedmiotu poświęconej relacjom nauki i systemów ideologicznych przywołuje się często - jako przykłady istotnych analiz (oraz inspirację do analiz własnych) - koncepcję zmian paradygmatów 
w nauce Thomasa Kuhna, mocny program socjologii wiedzy oraz studia na nauką i techniką (STS). Anton van Harskamp (2003) odnotowuje, że mocny program socjologii wiedzy oraz STS wskazują na wagę konfliktów kulturowych dla naukowych ustaleń (także w naukach ścisłych); autor podkreśla również relatywizujące poznanie naukowe skutki koncepcji Kuhna: skoro prawda jest cząstkowa i zależna od okoliczności społecznych, trudno dokonać wyboru między alternatywnymi teoriami. Konflikt twierdzi van Harskamp - jest zawsze częścią nauki; w szczególny sposób dotyczy to nauk społecznych, związanych ze światem wartości i subiektywizmem badanych podmiotów.

Wagę konfliktu jako integralnej części nauki dostrzega też Pietro Omodeo (2019: 5), konstatując, że różne wizje nauki związane są z odmiennymi wizjami przyszłości - wybór określonego paradygmatu to wybór obietnicy przyszłości. Przestrzega on zarówno przed pozytywistycznym pojmowaniem nauki, sprzyjającym projektom kulturowej hegemonii, jak i przed relatywizmem, który otwiera drogę populizmowi oraz dominacji „prawdy” silniejszego.

Podobne zagrożenie w relatywizmie dostrzega Zbyszko Melosik, pisząc o postmodernizmie (Melosik 2015): skoro prawda nie istnieje, powstaje pytanie, czemu służy uniwersytet i czy nie stanie się on areną walki o narzucanie poglądów? Każdy z przywoływanych autorów przedstawia swoje propozycje radzenia sobie z konfliktami i skutkami relatywistycznych epistemologii. Melosik proponuje nie rezygnować z pojęcia prawdy, a z prób narzucania prawdy uniwersalnej - zdaniem autora współistnienie różnych prawd i form wiedzy jest wartością.

Przywołany wcześniej Omodeo również sugeruje rezygnację nie tyle zideologiczności, co z uniwersalizmu: warto przedstawiać swoje własne koncepcje ze świadomością ich uwikłania w ideologię, dawać świadectwo różnorodnym partykularyzmom. Podobnie van Harskamp radzi prezentację wielości perspektyw. Zauważa jednak także, że nie zawsze dążenie do konsensusu i racjonalności komunikacyjnej jest realistyczne, ponieważ nie zawsze leży to w interesie stron. 
Sytuacja oczywiście komplikuje się, gdy w spór zaangażowane są siły społeczne spoza akademii, posługujące się odmiennymi (często potocznymi, nieskonceptualizowanymi, idealistycznymi lub instrumentalnymi) rozumieniami prawdy, wiedzy i ideologii. Artykułują one wobec akademii sprzeczne żądania, których legitymizacją jest służebna rola nauki wobec społeczeństwa: akademia powinna służyć prawdzie, być wolna od ideologii oraz otwarta na wolność debaty, stając się forum prezentacji przekonań i prawd, jednak z wyłączeniem fałszywych oraz ideologicznych. Czy spełnienie tych wymogów jest możliwe (i pod jakimi warunkami), rozważę w kolejnym rozdziale. W tej chwili chciałabym odnieść się jeszcze do samej praktyki sporów akademickich, wktóre angażują się organizacje zewnętrzne.

Organizacje zewnętrzne wobec akademii - niejednokrotnie umocowane w niej w postaci ruchów studenckich, kół naukowych czy zatrudnień poszczególnych aktywistów, ale działające w celach pozapoznawczych - dążą do przedefiniowania sporów o „prawdę” i wolność akademicką w ten sposób, by odpowiadały one ich ramie dyskursywnej. Przykładem mogą być cytowane powyżej zestawienia pojęć, sugerujące odbiorcom spoza akademii, że walka o „wolność akademicką” jest tożsama z walką o tradycyjną rodzinę i przeciw „ideologii gender”. W ten sposób akademia i jej wartości konstytutywne (wolność badań i nauczania) zostają wpisane w konflikt światopoglądowy, którego celem niejest konsensus, ale uzyskanie hegemonii. Akademia staje się zasobem oraz polem, na którym można próbować ustanawiać własne porządki poznawcze.

Dynamikę eskalacji w tego typu bataliach dobrze opisała Sarah Schulman (2016). Strony sporu chętnie przyjmują pozycję ofiary, wyolbrzymiając swą krzywdę i formułując zarzuty zgodnie z przyjętą przez siebiestronniczą optyką, która wyklucza samokrytycyzm. Taka definicja prowadzi do radykalizmu reakcji i uniemożliwia porozumienie. Schulman wskazuje na odpowiedzialność otoczenia społecznego za sposób przedstawiania i prowadzenia sporów. Stawia postulat, by dążyć do 
dialogu: uważa jednak, że porozumienie może być osiągnięte tylko w bezpośredniej międzyludzkiej komunikacji, bez medialnych, dekontekstualizujących i deformujących znaczenie zapośredniczeń - najlepiej twarzą w twarz, ewentualnie przez telefon, alejuż nie przez e-mail.

Felieton profesora Nalaskowskiego

Druga ze spraw, którą chciałam poddać analizie w kontekście mediatyzacji sporów akademickich, dotyczy nieco innego obszaru: wypowiedzi naukowców w debacie publicznej. J est więc to sytuacja, gdy sam uczony wychodzi poza akademię, publikując swoje wypowiedzi w mediach.

Spór o granice akademickiej wolności słowa poza uczelnią, który chciałabym tu opisać, zapoczątkowało opublikowanie przez profesora Aleksandra Nalaskowskiego felietonu Wędrowni gwałciciele w tygodniku „Sieci” 26 sierpnia 2019 r. W tym przypadku materiał do analizy stanowią nie tylko teksty medialne, ale i szczegółowa relacja Nalaskowskiego, zamieszczona przez niego wraz z dokumentacją sprawy w książce Wielkie zatrzymanie. Co się stało z ludźmi? (Nalaskowski 2020: rozdział Redefiniowanie uniwersytetu).

W swym felietonie, będącym krytyką marszów równości, profesor napisał między innymi:

„Wypełzają na ulice polskich miast. Odurzeni złą ideologią, zwykli nieszczęśnicy, których dopadła tęczowa zaraza. (...) Dawno już zgwałcili Warszawę, Poznań, Wroclawi Gdańsk. Niedawno brutalnie zdeflorowali Białystok. (...) J eden kochanek na tydzień. Ta ideologia uwielbia niestałość. Dlatego gwałci wszystko, co napotka na drodze. (...) Nie nadstawiajmy kolejnego policzka. Mamy tylko dwa i oba już dobrze obite. J eden przez komunistów i współczesnych lewaków, a drugi przez sodomitów. (...) Nie podawajmy ręki propagatorom tęczowej zarazy, nawracajmy niezdecydowanych i »obiektywnych«. Obudź się, profesuro, póki togi są jeszcze czarne, a nie tęczowe! Niech nasz opór będzie betonowy, głośny i jawny. (..) Zajmuję się pedagogiką, a ściślej fenomenem czasu 
w rozwoju dziecka. Ale jakże mam się temu oddawać, jeśli lubieżnie gwałcone są wartości-źródła, na których pedagogika wyrosła. J eśli pozwolę na podcięcie korzeni, to obumrze cała reszta" (Nalaskowski 2019).

Mimo iż profesor Nalaskowski nie podał w cytowanej publikacji swej afiliacji akademickiej, 11 września 2019 roku został zawieszony w pełnieniu obowiązków nauczyciela akademickiego na okres trzech miesięcy wraz ze wszczęciem postępowania wyjaśniającego w związku z podejrzeniem popełnienia przewinienia dyscyplinarnego. W uzasadnieniu decyzji prorektor Uniwersytetu Mikołaja Kopernika w Toruniu stwierdził:

„Do wszczęcia postępowania doszło w związku z opisanym wyżej artykułem, w którym zawarł Pan swoje przemyślenia związane z osobami nieheteronormatywnymi, wzywając między innymi członków społeczności akademickiej (profesorów) do określonych zachowań. Co istotne, w treści swojego artykułu odwołał się Pan do swojej pracy zawodowej (...). W orzecznictwie sądów powszechnych przyjmuje się, żejako zachowanie uchybiające godności nauczyciela akademickiego należy rozumieć zachowanie niegodne, sprzeczne ze standardami aksjologicznymi, składającymi się na etos nauczyciela akademickiego i to nie tylko w sferze zawodowej, ale także działalności publicznej i życiu prywatnym. (...) J ako osoba z wyższym wykształceniem musiał Pan sobie zdawać sprawę, że opublikowany przez Pana artykuł wpłynie na rozbudzenie emocji wśród społeczeństwa oraz skutkować będzie licznymi skargami, w tym kierowanymi do Rektora Uniwersytetu Mikołaja Kopernika w Toruniu, jako Pana pracodawcy. (...) Celem niniejszej decyzji jest (...) sygnał dla społeCzeństwa, a jednocześnie środowiska naukowego, że w Uniwersytecie nie ma przyzwolenia dla szerzenia mowy nienawiści oraz kwestionowania podstawowych praw czlowieka przysługujących wszystkim ludziom niezależnie od ich orientacji seksualnej" (cytat za: Nalaskowki 2020: 264-266).

Prorektor wskazuje więc między innymi na powód ostrej reakcji na felieton, jakim były skargi zgłoszone przez organizacje pozauniwersyteckie (między innymi Stowarzyszenie przeciw Antysemityzmowi i Ksenofobii „Otwarta Rzeczpospolita” i Stowarzyszenie na Rzecz Lesbijek, Gejów, 
Osób Biseksualnych, Osób Transpłciowych oraz Osób Queer „Pracownia Różnorodności”) i konieczność zdecydowanego zajęcia stanowiska w sporze światopoglądowym.

Tym razem sam Nalaskowski swym felietonem wpisał się w ideologiczną ramę: „ideologia LGBT” (nie wiadomo, w jakim stosunku pozostająca do osób o nienormatywnej orientacji seksualnej), powiązana z lewicą (dziedzictwem komunizmu), zagraża fundamentom cywilizacji i podstawowym wartościom, których trzeba bronić. Nalaskowski w felietonie powiązał idee wojny kulturowej z powinnościami naukowców jako tych, którzy powinni stawiać opór „tęczowej zarazie” i w ten sposób ratować również możliwość prowadzenia badań. W książce twierdzi także, że publicystyka stanowi dla niego sposób „wdrażania” i popularyzowania swych wniosków z pracy naukowej (Ibidem, s. 243).

Podobnie jak w wypadku prof. Budzyńskiej, liberalne i prawicowe media zajmowały spolaryzowane stanowiska na każdym etapie postępowania wyjaśniającego, które zostało umorzone w grudniu 2019 roku po odwołaniu złożonym przez prof. Nalaskowskiego i jego prawnika, a następnie wznowione w kwietniu 2020 roku w związku z zażaleniem na umorzenie, złożonym przez Stowarzyszenie „Pracownia Różnorodności”, oraz stwierdzeniem uchybień proceduralnych w postępowaniu, polegających między innymi na tym, że prof. Nalaskowski nie złożył wyjaśnień w sprawie. W konflikt zaangażowały się organizacje społeczne, między innymi aktywna na polu wojen kulturowych Fundacja Centrum Życia i Rodziny, która ogłosiła w internecie petycję Murem za Profesorem Aleksandrem Nalaskowskim, jaką podpisało ponad 50000 osób. Na stronie petycji napisano między innymi:

„Uniwersytety muszą być miejscem swobodnej debaty, wolności prowadzenia badań naukowych oraz stosowania jednakowych standardów i wymogów etycznych wobec wszystkich członków środowiska akademickiego. Nie możemy pozwolić, by zamieniły się $\mathrm{w}$ inkubatory noeomarksistowskiej ideologii i ochronki dla jej akuszerów. (...) Trudno oprzeć się wrażeniu, że pod hasłem „walki z dyskryminacją" mamy do 
czynienia z narzucaniem ogółowi społeczeństwa światopoglądu radykalnej mniejszości" (Murem za Profesorem Aleksandrem Nalaskowskim 2019).

Zarówno prawicowe media i organizacje, jak i profesor Nalaskowski, wskazują na brak symetrii w traktowaniu idei lewicowych i prawicowych w przestrzeni akademickiej. Nalaskowski skarży się dodatkowo na samoograniczanie przez uczelnie autonomii uniwersyteckiej w rozwiązywaniu wewnętrznych konfliktów:

„Trudno (...) wyobrazić sobiejakąkolwiek wolność słowa czy poszukiwanie prawdy wewnątrz uczelni ulegającej presji zewnętrznej. Tymczasem coraz bardziej widoczna jest bierność i wręcz bezradność społeczności akademickiej wobec prób narzucenia jej metod i kierunków postępowania" (Nalaskowski 2020: 214).

Zarówno w sprawie Budzyńskiej, jak i Nalaskowskiego, oskarżeni profesorowie wskazywali na niedostateczne zaangażowanie uczelni w działania wyjaśniające czy mediacyjne, a nadmierne w reagowanie na zewnętrzne naciski. Nalaskowski ponadto skrytykował język debaty publicznej w sporze w jego sprawie (zbyt ostre i niestosowne sformułowania) oraz wybiórcze i niezgodne zjego intencjami autorskimi cytowania felietonu (Nalaskowski 2020: 202, 204, 218). Wad tych (ostrość sformułowań, fragmentaryczność oglądu) nie dostrzegł w swoim tekście, któremu (niezależnie od jego konwencji gatunkowej felietonu) przypisywał nie tylko funkcję wyrażania osobistych poglądówi wrażen, alei popularyzacji nauki.

W konflikcie wokół tekstu Nalaskowskiego najciekawsze i najważniejsze wydają mi się właśnie opinie dotyczące kondycji debaty publicznej i związanych z nią powinności i ograniczeń naukowców. W uzasadnieniu decyzji o umorzeniu postępowania dyscyplinarnego władze uniwersyteckie powołują się na opinię biegłego językoznawcy, który stwierdził: 
„Niektóre spośród zamieszczonych w felietonie określeń mają negatywne konotacje społeczne, lecz w kontekście dyskursu, który toczy się w przestrzeni medialnej, są one wyrazem poglądów autora felietonów i nie mają charakteru znieważającego. Należy je raczej traktować jako sposób ukształtowania wypowiedzi, który wpisuje się w szersze ramy debaty publicznej" (Ibidem: 279).

Inną opinię wyraziło Prezydium Konferencji Rektorów Akademickich Szkół Polskich w stanowisku z dnia 23 września 2019 r.:

„W środowisku akademickim powinniśmy szanować wiedzę i odwoływać się do niej przy formułowaniu naszego stanowiska. Powinniśmy dawać wzór powściągliwości w użyciu języka - język może ranić. Użycia słowa „zaraza” już sprowokowało do odkażania miast. Apelujemy, by obie strony nie podsycały dalej napięć. Także strona uznająca wolność sztuki bez ograniczeń, czasem kpiąc z symboli religijnych, prowadzi do obrażania uczuć osób wierzących. Coraz wyraźniej radykałowie obu stron wpływają na ogólną atmosferę społeczną. Dalsza eskalacja tego konfliktu jest groźna dla wszystkich!” (cytat za Ibidem: 273).

Być może gdyby w swym felietonie (pełniącym wszak w zamyśle autora funkcje popularyzacyjne i apelującym do profesury o określone postawy) Aleksander Nalaskowski operował bardziej precyzyjnym językiem i zrezygnował z prowokacyjnej retoryki, lepiej osiągnąłby swoje cele. Wyrażony w ostatnim akapicie felietonu niepokój autora o status wartości tradycyjnych w nowoczesnym społeczeństwie i ich związek z określonymi dziedzinami nauki jest wart rozważenia bez blokujących głębszą refleksję ram dyskursywnych wojen kulturowych. Proponowane w stanowisku Prezydium KRASP ograniczenie wolności słowa uczonych biorących udział w debacie publicznej - używanie neutralnego języka, odwoływanie się do badań, a więc również dążenie do ujęcia problemów w sposób wielostronny i precyzyjny - jest takim ograniczeniem wolności osobistej, które pozwala realizować akademicki etos i działa nie tylko w interesie społecznym, lecz i w interesie prezentowanych idei: w wypadku omawianego felietonu konserwatywnych. 
Fakt, że najbardziej słyszalnymi w przestrzeni publicznej rzecznikami idei konserwatyzmu są aktywiści wojen kulturowych, pozwala je łatwo i niesprawiedliwie dyskredytować, właśnie ze względu na dyskursywne i merytoryczne nadużycia związane z ideologiczną ramą (takie jak fragmentaryczność i stronniczość ujęcia, asocjacyjne ciągi pojęciowe przywoływane niezależnie od kontekstu, emocjonalny język przekazu, w którym nadużywa się apokaliptycznych tropów, stawiając siebiew pozycji ofiary, a innych - przedstawiając jako przebiegłych wrogów).

Podobnie ścisłe powiązanie w przestrzeni wojen kulturowych interesów osób nieheteronormatywnych z ideologią lewicową, a zwłaszcza mało zrozumiałą dla szerszej publiczności teorią queer, niekoniecznie służy interesom tej grupy i pozwala unikać debaty o tych interesach pod pretekstem oddalania roszczeń radykalnych mniejszości ${ }^{5}$. Trudną rolą nauki byłaby próba wyjścia poza ten impas poprzez zmianę formy i treści dominujących w przestrzeni publicznej przekazów. Podjęcie tej roli przez akademików oznacza mniejszą swobodę komunikowania osobistych odczuć i poglądów, nie oznacza jednak rezygnacji ze służenia swoim przekonaniom.

J ak zauważa Stanley Fish (2019), wolność słowa akademików w przestrzeni publicznej nie ma nic wspólnego z wolnością akademicką (wolnością badań i nauczania). Akademik jako obywatel może mówić, co chce: wolność słowa oznacza tu wolność od ingerencji państwowej, ale nie od konsekwencji wypowiedzi. Te, twierdzi Fish, ponosimy zawsze - w życiu osobistym i zawodowym. Większość akademickich sporów o wolność wypowiedzi profesorów powinna być zdaniem Fisha rozpatrywana nie w kontekście wolności akademickiej czy wolności słowa, a jako konflikty między zatrudnionym a pracodawcą - o zobowiązania i ograniczenia związane z rolą zawodową. Wolność słowa, podkreśla Fish, niejest wartością akademicką - jest nią natomiast precyzja wypowiedzi.

\footnotetext{
5 Sądzę, że warto oddzielić tu interesy grup społecznych od skuteczności wybranych działań ich rzeczników. Skuteczność działań jest wypadkową wielu czynników, a interesy osób nieheteronormatywnych bywają przez nie różnie postrzegane (por. np. Mizielińska 2017).
} 
W tym kontekście warto przywołać ciekawe ustalenia Michaela Evansa (2016), dotyczące amerykańskiej przestrzeni publicznej - wydaje się jednak, że podobne badanie w Polsce mogłoby dać zbliżone rezultaty (ze względu na podobnąjak w USA polaryzację światopoglądową związaną z wojnami kulturowymi). W książce Seeking Good Debate. Religion, Science, and Conflict in American Public Life autor prezentuje rezultaty swych badań dyskursu medialnego oraz opinii o kondycji debaty publicznej, zebranych metodą wywiadów pogłębionych. Wedle ustaleń autora debata publiczna na tematy religijne w USA została zdominowana przez religijną prawicę, zaś naukę reprezentują rozpoznawalne osobistości o niedeliberatywnych poglądach. Te dominanty wpływają na wybór kwestii chętnie tematyzowanych (repertuar wojen kulturowych) i marginalizowanych (np. ubóstwo). Sprawiają też, że dla umiarkowanych przedstawicieli nauki i religii wiarygodność oznacza pozostawanie poza sferą publiczną.

Respondenci Evansa, niezależnie od swojej orientacji światopoglądowej, nisko ocenili jakość debaty publicznej. Odnosili się krytycznie do reprezentantów zajmujących w debacie zdecydowane pozycje wymierzone w inne stanowiska, używających argumentów, które nie sprzyjają deliberacji.

Niekoniecznie jest więc tak, że debata publiczna wyraża nastroje spolaryzowanego społeczeństwa, a nawet szerszych grup społecznych, w imieniu których głos zabierają dominujący w debacie reprezentanci. Wyraża ona jedynie poglądy i interesy węższych grup, które donośnie i zdecydowanie zabierają w niej głos - pozostali oczekiwaliby bardziej otwartej debaty, lecz zostają z niej wykluczeni (lub sami się wykluczają) przez przyjęte ramy lub deficyt medialnej uwagi. Nie jest też jednak tak, że debata w obecnym kształcie nie wpływa na życie społeczne: współkształtuje ona zarówno pole nauki, jak i religii.

Rozważania Evansa zachęcają do namysłu nad innymi możliwościami ksztaltowania debaty publicznej w ten sposób, by lepiej odpowiadała ona szeroko akceptowanemu modelowi deliberatywnemu. Istotna 
rola w tym przedsięwzięciu mogłaby przypaść nauce, choć niewątpliwie istnieją inne niż wojny kulturowe czynniki stojące na przeszkodzie jego realizacji (rynkowa sytuacja mediów, niedeliberatywny sposób budowania publicznego autorytetu nauki jako wiedzy pewnej).

Jakie regulacje są nam potrzebne, by chronić wartości akademickie?

W ostatnich latach w krajach anglosaskich podjęto kilka inicjatyw społecznych, mających na celu obronę akademickiej wolności słowa. W latach 2015-2018, z zamiarem wpłynięcia na instytucje i opinię publiczną, ukazywały się corocznie Free Speech University Rankings politycznego (konserwatywnego) magazynu „Spiked”, które oceniały uniwersytety brytyjskie wedle stopnia wolności od wewnętrznie narzuconej cenzury. Ewaluowane były polityki wewnętrzne oraz działania, takie jak zakazywanie wystąpień określonych mówców. Uczelnie zostały podzielone na trzy kategorie: w czerwonej znalazły się te, które aktywnie cenzurowały wypowiedzi, w żółtej te, które wdrażały nadmierne regulacje; zielona kategoria zarezerwowana była dla szkół, jakie nie wprowadzały w życie restrykcyjnych polityk i praktyk. W roku 2018 54\% uczelni brytyjskich otrzymało status czerwony, 40\% żółty, a jedynie 6\% zielony. Najgorzej wypadły między innymi uniwersytety znajdujące się w czołówce światowych rankingów jakości, na przykład University of Oxford (Free Speech University Rankings 2018 2018).

Oceniono też osobno działania administracji oraz organizacji studenckich - te ostatnie okazały się o wiele bardziej rygorystyczne, co odpowiadałoby moim obserwacjom polskich polityk i działań restrykcyjnych: to zaangażowani ideowo studenci oraz organizacje studenckie, często powiązane z ruchami społecznymi, są zazwyczaj inicjatorami protestów, zakłóceń wydarzeń czy regulaminowych regulacji. W rankingu "Spiked” z roku 2018 wskazano na dominujące kategorie wykluczeń: to grupy religijne, radykalna prawica, transfobia oraz krzywdząca mowa - ta ostatnia eliminowana głównie przez polityki „bezpiecznych 
przestrzeni" (Safe Spaces, wolnych od krzywdzącej mowy) tworzonych przez organizacje studenckie (Ibidem).

Rankingi „Spiked” zauważone zostały przez prawicową prasę w Polsce, podobnie jaki inne przedsięwzięcie na rzecz wolności wypowiedzi: amerykańska Heterodox Academy (HA), organizacja na rzecz różnorodności opinii na uczelniach, założona przez akademików o poglądach określanych przez nich jako centrystyczne. Zdaniem działaczy HA otwarta debata, wielość punktów widzenia i konstruktywne spory przygotowują studentów do uporania się ze złożonością współczesnego świata. Sprzyjanie różnorodności jest więc istotniejsze niż zapewnienie komfortu studentom w „safe spaces” - dyskomfort uznany zostaje za mający istotny wymiar dydaktyczny.

HA w latach 2016-2017 publikowała ranking Heterodox Academy Guide to Colleges, przygotowała też wytyczne dla kandydatów na studia, jakimi powinni się kierować wybierając uczelnię. Kryterium oceny był tym razem klimat sprzyjający swobodnej ekspresji, oceniany na podstawie badań samopoczucia studentów. Pytania dotyczyły między innymi subiektywnie odczuwanej swobody wyrażania opinii w kwestiach politycznych, rasowych, genderowych, religijnych i na tematy związane z seksualnością. W roku 2019 58,5\% badanych wskazało na problemy z wypowiadaniem swojego zdania bez obaw na przynajmniej jeden z kontrowersyjnych tematów - tematyka zależała od badanej grupy (największy opór przed wypowiadaniem się otwarcie odczuwali konserwatyści). 55\% studentów oceniło klimat swych uczelni jako niesprzyjający nieskrępowanemu wyrażaniu myśli (Stiksma 2020).

Kandydatom na studia HA doradza przyjrzenie się, czy na uczelni jest miejsce dla kontrowersyjnych mówców reprezentujących różne punkty widzenia i czy ich wystąpieniom nie towarzyszą protesty. Innym kryterium, które powinni wziąć pod uwagę kandydaci, jest obecność zachęt do wypowiadania różnorodnych opinii, wyrażana przez wykładowców podczas zajęć oraz w sylabusach. 
Wykładowcom i administratorom HA sugeruje przeprowadzanie badań klimatu na kampusie, sygnalizowanie otwartości na różnorodność w rozmaitych kontekstach (np. w ogłoszeniach dotyczących zatrudnienia), organizowanie debat i zapraszanie mówców o różnych poglądach, w tym przywódców religijnych. Przywiązanie do akademickich standardów (kultura debaty, ugruntowanie w badaniach, ocenianie wyłącznie z wykorzystaniem profesjonalnych kompetencji) HA łączy więc z otwartością na poznanie innych typów dyskursów: nie jest jasne, w jakiej relacji są te inne dyskursy do dyskursu naukowego, nacisk zostaje położony na wartość ekspresji różnic. Lektura dokumentów HA wskazuje na potrzebę, by wartości akademickie - tradycyjne, etosowe, przekazywane przez praktykę - zapisywać explicite w postaci kontraktów, deklaracji i polityk (Heterodox Academy b.d.).

W obu opisywanych przedsięwzięciach uwagę zwraca ich uwikłanie w wojny kulturowe; obie inicjatywy bywały oceniane nie tylko jako próba ograniczenia zbytnich rygorów politycznej poprawności i walka $\mathrm{z}$ „kulturą unieważnienia” (cancel culture - dyskredytacji osób, które zachowały się w sposób niezgodny zzasadami poprawności politycznej), ale i próba wsparcia obecności konserwatystów na kampusach.

Krytycy zauważają niechęć inicjatorów HA do studiów genderowych i rasowych oraz niebezpieczeństwo, że zbytnia otwartość doprowadzi do osłabienia rygorów naukowych przez konieczność wysłuchiwania nienaukowych sądów i grup interesów, które mogą posługiwać się dezinformacją (Zabdyr-J amróz 2017). W licznych opracowaniach z zakresu academic freedom studies domaganie się nieskrępowanej wolności słowa, a zwłaszcza równowagi światopoglądów i opinii na kampusach rozpoznawane jest jako taktyka służącą określonej agendzie ideologicznej (zazwyczaj konserwatywnej) i skierowana przeciw innym ideologiom (Fish 2014; Wallach Scott 2019; Giroux 2010; Wilson 2010; Bromwich 2015; Cole 2015).

J ak zauważa Stanley Fish (2019) „wolny rynek idei”, wskazywany przez konserwatystów jako cenne narzędzie dla akademii (Williams 
2016), nie służy wyłonieniu idei najlepszych - temu służy rygor pracy naukowej wolnej od politycznych zaangażowań, opartej na dyskusji ekspertów. Akademiajest miejscem merytokracji, niedemokracji idei (Fish 2014).

Wydarzenia takie jak prelekcje zaproszonych gości na kampusach nie mają zdaniem Fisha związku z wolnością akademicką, ponieważ nie służą w opinii autora realizacji głównej misji akademii: badaniom i nauczaniu. Kontrowersje z nimi związane są problemem administracyjnym, a celowość organizacji tego typu imprez powinna być rozważana w związku z edukacyjną i rozrywkową rolą niezwiązanego z programem nauczania życia akademickiego na kampusach (Fish 2019). Podobnie jak Fish, J oan Wallach Scott (2019) podkreśla, że wolność akademicka nie jest tożsama z wolnością słowa: wolność akademicka oznacza przywiązanie do jakości badań (co wyklucza demokratyczny proces produkcji wiedzy), a prawo do wypowiedzi nie pociąga za sobą konieczności wyrażania szacunku dla wszystkich głoszonych treści.

Inicjatywa ustawodawcza Instytutu na rzecz Kultury Prawnej Ordo luris

W tym szerszym kontekście warto analizować propozycję nowelizacji ustawy Prawo o szkolnictwie wyższym i nauce Instytutu na rzecz Kultury Prawnej Ordo Iuris, inspirowaną ideami Heterodox Academy, wysuniętą w kontekście postępowania dyscyplinarnego w sprawie prof. Budzyńskiej i następnie podjętą przez Ministerstwo Nauki i Szkolnictwa Wyższego.

Instytut Ordo Iuris zaproponowal, by wolność słowa na uczelniach (wopinii Instytutu nierealizowaną właściwie) zapewnić ustawowo i dyscyplinarnie. Nowelizacja ustawy obejmować miałaby wpisanie do niej, prócz dotychczas wymienionych wolności - wolności badań i nauczania - również wolności „prezentowania poglądów”. W przypadku odwołania przez władze rektorskie spotkań czy konferencji organizowanych 
przez pracowników i organizacje studenckie, pracownikom i organizacjom miałoby przysługiwać odwołanie: najpierw do uczelnianej komisji odwoławczej, złożonej z siedmiu pracowników naukowych z różnych dziedzin, a następnie do komisji przy Radzie Głównej Nauki i Szkolnictwa Wyższego, której siedmiu spośród dziewięciu członków miałby mianować minister na podstawie wskazań różnych organów akademickich. Minister również mógłby nałożyć na rektora ograniczającego wolność akademicką karę w wysokości 50000 złotych.

Zaproponowano też przy okazji rozszerzenie katalogu zadań stawianych przed uczelnią o „umacnianie poszanowania aksjologii państwa”, co nie ma bezpośredniego związku z wolnością akademicką - uczelnia powinna wzmacniać aksjologię wyrażoną w konstytucji RP, w tym „kulturowe chrześcijańskie dziedzictwo" (inne wartości nie są w uzasadnieniu do nowelizacji wymienione). Ten zapis ma zapewne chronić w sposób szczególny idee konserwatywne, by nie ucierpiały wskutek realizacji zasad wolności akademickiej do wygłaszania poglądów. Uzasadnienie nowelizacji wskazuje na bezpośrednią przyczynę potrzeby regulacji akademickiej wolności słowa:

„J ednym z miejsc mających szczególne znaczenie dla realizacji wolności słowa są ośrodki akademickie, w których swobodne zdarzanie się odmiennych światopoglądów powinno zapewniać poszanowanie pluralizmu społecznego. Dodatkowo takiemiejsca pełniaistotna funkcję wzakresie pozyskiwania oraz rozpowszechniania informacji. (...) O ile w zakresie np. nauk inżynieryjno-technicznych czy tez nauk ścisłych i przyrodniczych możliwość weryfikacji informacji jest większa, o tyle w naukach społecznych czy z dziedzin humanistycznych falsyfikowalność haseł nie ma nigdy charakteru ostatecznego. Na ośrodkach akademickich ciąży zatem szczególny wymiar odpowiedzialności społecznej polegającej na umożliwieniu prezencji różnych poglądów, a co za tym idzie również wykuwania się dyskursów naukowych w oparciu o poznawanie i weryfikacje odmiennego sposobu patrzenia na dane zjawiska. (...) Wprowadzenie 
omawianej regulacji wydaje się niezbędne ze względu na fakt, iż na przestrzeni ostatnich dziesięciu lat miało miejsce kilkadziesiąt przypadków ograniczania wolności akademickiej. (...) Tego rodzaju działania ze stron władz uczelni mogą prowadzić do uniemożliwienia realizacji wolności do prezentowania światopoglądu, który odnosi się do istotnych zagadnień społecznych będących przedmiotem debaty politycznej oraz znajdujących swoje uzasadnienie w szeroko rozumianym dyskursie akademickim" (Projekt nowelizacji ustawy Prawo o szkolnictwie wyższym i nauce 2020).

Wskazanym kilkudziesięciu przypadkom ograniczenia wolności akademickiej Instytut Ordo Iuris poświęcił osobny raport (Lista najważniejszych ograniczeń wolności akademickiej w Polsce 2020). Wśród przywołanych przykładów znalazły się postępowania dyscyplinarne profesorów Budzyńskiej i Nalaskowskiego, a także odwołania debat i konferencji z udziałem gości (na tematy z repertuaru wojen kulturowych, np. syndromu poaborcyjnego, aborcji, in vitro) oraz spotkań z politykami prawicy. W spisie znalazła się również zlikwidowana wystawa pro-life. J ak widać w raporcie zestawione są zdarzenia z różnego porządku, a najwięcej „ograniczeń wolności akademickiej” dotyczy zaproszonych gości spoza uczelni, nie samych akademików i naruszenia ich praw.

Ordo Iuris nie wspomina o przypadkach odwołania wykładów akademików o lewicowej orientacji światopoglądowej, jakie miały miejsce w latach, które uwzględnia opracowanie, na przykład bioetyka prof. Petera Singera (w roku 2010) i filozofa prof. Jana Hartmana (w roku 2013). Tego typu zdarzeń jest mniej, lecz są one także następstwem wojen kulturowych (protesty organizacji prawicowych). Sposoby uzasadniania przez uczelnie odwołania imprez (nienaukowy charakter, brak moderatora i zapewnienia różnorodności punktów widzenia, niedopełnienie wymogów formalnych, zagrożenie incydentami zakłócenia porządku) Ordo Iuris ukazuje jako pretekstualne i dowodzące dyskryminowania określonych światopoglądów (naruszania wolności akademickiej). 
Przygotowanym przez Ordo Iuris opracowaniom i projektom towarzyszyła ich promocja ma liście mailingowej. W newsletterze z 26 czerwca 2020 roku (w archiwum autorki) napisano między innymi:

„Tłumienie wolności słowa i badań naukowych to jedne z przyczyn, dla których kolejny raz ani jedna z polskich uczelni nie znalazła się wśród pierwszych 500 uniwersytetów świata wżadnym z istotnych rankingów. Z pomocą naszych Darczyńców zrobimy wszystko, by polskie uniwersytety na nowo stały się przestrzenią wolnej debaty akademickiej oraz miejscem poważnych badań służących poznaniu prawdy o otaczającym nas świecie i procesach, jakie w nim zachodzą. Dlatego z satysfakcją przyjęliśmy zaprezentowany przez Ministerstwo Nauki i Szkolnictwa Wyższego projekt ustawy o wolności akademickiej, w dużej części powtarzający rozwiązania proponowane przez ekspertów Ordo Iuris. Teraz chcemy rozpocząć szeroką kampanię społeczną na rzecz pilnego przyjęcia zmian prawnych. Kolejnym krokiem powinno być zreformowanie systemu finansowania szkolnictwa wyższego i badań naukowych, które w obecnej formie utrwala niewydajne układy akademickie i tłumi badaczy gotowych do odważnego zakwestionowania dominującej na wielu wydziałach ideologicznej linii. O ile miliony płyną na granty poświęcone gender studies i teorii queer, to finansowanie studiów nad rodziną i współczesnymi zagrożeniami cywilizacyjnymi pozostaje niemal niedostępne. Tymczasem jedynym kryterium w tych sprawach powinna być prawda i rzetelna metoda naukowa".

Jak zatem widać z przedstawionego zestawienia dokumentów, wobec projektu Ordo Iuris mogą pojawić się podobne wątpliwości jak w przypadku Heterodox Academy - wolność akademicka w tym przypadku oznacza nie tyle równoprawność idei, co zwalczanie jednych, a obronę innych (przede wszystkim na gruncie nauk społecznych i humanistycznych), w dużej mierze za pomocą sił zainstalowanych poza akademią: organizacji społecznych i polityków, którym akademia jest zobowiązana dostarczyć przestrzeni do wygłaszania poglądów. 
Projekt ustawy6, który 28 stycznia 2020 roku przedstawiło Ministerstwo Nauki i Szkolnictwa Wyższego, powtórzył w dużym stopniu rozwiązania proponowane przez Ordo Iuris; zrezygnowano z zapisu o ochronie aksjologii państwa i zmniejszono liczbę członków mianowanych przez ministra wkomisji odwoławczej, nazwanej „komisją do spraw wolności” (czterech z dziewięciu członków komisji). O naruszeniach wolności mowa jest tylko w stosunku do członków wspólnoty akademickiej. Dodano też zapis „nikt nie może ponosić negatywnych konsekwencji zgodnego z prawem korzystania z wolności”, który wskazuje na bezpośrednie powody podjęcia inicjatywy ustawodawczej: postępowania dyscyplinarne wobec pracowników uczelni (MNiSW przedstawiło założenia nowelizacji Konstytucji dla Nauki 2020).

Negatywną opinię o projektowanej nowelizacji upubliczniła Rada Główna Nauki i Szkolnictwa Wyższego (Uchwała nr 132/202o Rady Gtównej Nauki i Szkolnictwa Wyższego..., 2020), wskazując, żedotychczasowo zagwarantowany katalog wolności akademickich („wolność nauczania, twórczości artystycznej, badań naukowych i ogłaszania ich wyników oraz autonomia uczelni") jest wyczerpujący, a prawo do wyrażania poglądów gwarantuje obywatelom konstytucja - na uczelni nie ma miejsca na prezentację poglądów nieugruntowanych w wiedzy naukowej. RGNiSW uznała też za niewłaściwe i niezgodne z zasadą autonomii przeniesienie odpowiedzialności za rozstrzyganiesporów poza uczelnię. Rada zaproponowała, by proponowane zmiany zastąpić przepisem wyłączającym z przewinień dyscyplinarnych wypowiedzi, które odpowiadają standardom akademickim (poprawne formalnie, niesprzeczne z wiedzą naukową).

Powyższe stanowisko poparło Prezydium Konferencji Rektorów Akademickich Szkół Polskich (Stanowisko Prezydium KRASP w sprawie projektu ustawy..., 2020), dołączając do swego oświadczenia opinię Komisji ds. Organizacyjnych i Legislacyjnych KRASP i Uchwałę

\footnotetext{
${ }^{6}$ W tym samym czasie, 21 stycznia 2020 r., w Sejmie RP ukonstytuował się, złożony wyłącznie z polityków partii prawicowych, Parlamentarny Zespół ds. Walki z Cenzurą na Uczelniach.
} 
Komisji ds. Komunikacji i Odpowiedzialności Społecznej. Komisja ds. Organizacyjnych i Legislacyjnych KRASP (KOiL) wskazała na niejasność sformułowania „Wolność wyrażania poglądów” i konieczność mieszczenia się „poglądów” w akademickich rygorach intelektualnych. Za niebezpieczne dla autonomii uczelni uznała poddanie wszystkich kategorii wolności akademickich (a więc w istocie całego działania uczelni) kontroli komisji usytuowanej poza uczelnią, niemającej charakteru eksperckiego, której tryb wyboru otwiera drogę do jej upolitycznienia. Zdaniem KOiL proponowana zmiana przepisów może przynieść skutki przeciwne do wyrażonych w intencjach wnioskodawców.

Komisja ds. Komunikacji i Odpowiedzialności Społecznej (KKiOS) podkreśliła, że wolność oznacza też odpowiedzialność, która wymaga prowadzenia badań i odwoływania się do koncepcji „poddanych gruntownej ocenie”. Zdaniem komisji gwarancją realizowania wolności akademickiej jest autonomia uczelni, niepodlegającej w tym względzie zewnętrznej kontroli.

Do podobnych argumentów w swej krytycznej ocenie nowelizacji odwołała się Krajowa Sekcja Nauki NSZZ „Solidarność” (Opinia Krajowej Sekcji Nauki NSZZ „Solidarność”... 2020) oraz organizacje społeczne naukowców: Obywatele Nauki - wyrażając „stanowczy sprzeciw” (Opinia ON ws. projektu nowelizacji ustawy..., 2020) i Komitet Kryzysowy Humanistyki Polskiej (Komitet Kryzysowy Humanistyki Polskiej o inicjatywie min. Jarosława Gowina i Ordo Iuris..., 2020). Lewicowa organizacja studencka Uniwersytet Zaangażowany w swej negatywnej opinii wskazała dodatkowo na istotny dla sprawy kontekst wojen kulturowych i wcześniejszych sporów o prawo do zabierania głosu na terenie uczelni - wyrażając obawę, że nowelizacja posłużyć może do organizacji na kampusach wydarzeń niemających charakteru merytorycznego, 
a propagandowy i lobbystyczny (Koniec autonomii uczelni publicznych w Polsce?..., 2020) ${ }^{7}$.

Pozytywną opinię o projekcie nowelizacji opublikował Instytut Ordo Iuris (Stanowisko Instytutu na rzecz kultury prawnej Ordo Iuris $w$ sprawie projektu ustawy..., 2020). Zgłaszając uwagi do projektu Instytut zaproponował rozwiązania idące znacznie dalej niż te, które zamieścił we własnej wcześniejszej propozycji. Członków komisji odwoławczej zewnętrznej wobec uczelni miałyby wskazywać w dużej mierze organy władzy (Sejm, Senat, Prezydent, Trybunał Konstytucyjny): taka decyzja uzasadniona zostaje koniecznością „legitymacji demokratycznej" społeczeństwa. Komisja zamiast rekomendacji w sprawie miałaby wydawać decyzje administracyjne w trybie natychmiastowym (maksymalnie w ciągu 96 godzin) - tak, by wydarzenia będące przedmiotem sporu miały szanse się odbyć.

Ordo Iuris powraca też do swojego pomysłu nałożenia kar na uczelnie, które zdaniem ministra łamią wolność akademicką: kary te miałyby być wymierzane niezależnie od decyzji komisji odwoławczej, zgodnie z oceną ministra. Instytut podkreśla funkcje kontrolne komisji - celowość objęcia kontrolą również Polskiej Akademii Nauk oraz zdawania przez komisję corocznych raportów z „respektowania podstaw systemu szkolnictwa wyższego i nauki przez instytucje tworzące system”.

Tym razem Ordo Iuris pisze o wpłynie na kształt komisji „partii (albo koalicji) rządzącej”, propozycja jej upolitycznienia jest więc sformułowana wprost i ukazana jako demokratyczny udział społeczeństwa w kontroli instytucji jemu służącej. W uzasadnianiu swych propozycji i działań związanych w obroną wolności akademickiej Ordo Iuris zestawia - sugerując ich równoznaczność - wartości akademickie (bezstronność, rzetelność, metoda naukowa, otwarta debata) z celami swej własnej organizacji (obrona wartości tradycyjnych, ze szczególnym

\footnotetext{
7 Krytycznie do projektu regulacji odniósł się również Aleksander Nalaskowski, odnotowując negatywne opinie o propozycji nowelizacji, formułowane przez naukowcówów niezależnie od ich orientacji światopoglądowej (Nalaskowski 2020: 215-216).
} 
uwzględnieniem rodziny i religii chrześcijańskiej, poprzez ugruntowywanie ich w polskim porządku prawnym - i przeciwdziałanie procesom je osłabiającym).

Instytucje nauki są dla Ordo Iuris jednym zistotnych pól umacniania „tradycyjnego ładu społecznego" - ze względu ich misję kształcenia elit. Dlatego też Instytut proponuje kompleksowe zmiany w systemie nauki: plany takie dobrze korespondują z ugruntowanym w ostatnich dwóch dekadach dyskursem medialnym, w którym dominuje krytyka rozlicznych uczelnianych „patologii” i żądanie ich naprawy za pomocą odgórnie narzuconych rozwiązań prawnych.

W newsletterze z 10 stycznia 2020 roku (w archiwum autorki) Ordo Iuris zapowiada:

„W najbliższych planach mamy również przygotowanie kolejnych projektów, które pozwolą chronić wolność akademicką i uniemożliwią ataki na naukowców wiernych sumieniu. Niezbędne jest przede wszystkim uregulowanie kwestii związanych z transparentnością finansowania badań naukowych czy jawnością przyznawania habilitacji”.

Warunki realizacji wolności akademickiej

Próby odgórnego (prawnego, regulaminowego) zapewnienia różnorodności światopoglądowej na uczelniach (również w tych wypadkach, gdy ich autorom faktycznie chodziło o pluralizm, nie zaś osiągnięcie hegemonii), są zazwyczaj krytykowane jako przeciwskuteczne, niesłużące wolności akademickiej. Przykładem może być ocena amerykańskiej inicjatywy Academic Bill of Rights, dokonana przez Marię Aleksandrę Vanney, autorkę, która wyraża również zaniepokojenie zdominowaniem świata akademickiego przez ideologie liberalne, eliminujące z kampusów idee konserwatywne (Vanney 2019).

Academic Bill of Rights (Karta Praw Akademickich, ABOR) jest zbiorem postulatów organizacji Students for Academic Freedom, powstałej z inicjatywy konserwatysty Davida Horowitza. Konserwatywne głosy 
w obronie wolności słowa nie zawsze włączają się w dążącą do eliminacji wroga logikę wojen kulturowych. Dla konserwatystów, będących na uczelniach amerykańskich w mniejszości, popieranie pluralizmu może być zagwarantowaniem sobie większej swobody ekspresji. Twórcy ABOR proponują instytucjonalizację różnorodności poprzez zatrudnianie pracowników z uwzględnieniem wielości perspektyw i metodologii oraz zapewnienie w programach nauczania różnych punktów widzenia. J ak wskazuje Vanney, prawne zadekretowanie podobnych zasad (które jeszcze wUSA nie miało miejsca) mogłoby doprowadzić do zatrudniania za poglądy i eliminowania z sal wykładowych zagadnień kontrowersyjnych - wobec niemożności jasnego ustalenia, czym jest odpowiednia wielość punktów widzenia i jakją ewaluować. Nie mniej ważna jest kwestia ustanowienia zewnętrznej względem akademii instancji kontroli praw.

„Podobnie jak w wielu debatach dotyczących wolności akademickiej, ważną kwestią jest nie tylko to, jakie mają być właściwe zasady, ale także kto będzie miał prawo je egzekwować. (...) Wolność akademicka opiera się na autonomii instytucjonalnej uniwersytetów. Karta Praw Akademickich, przy deklarowanej próbie wzmocnienia wolności akademickiej, wistocieją osłabia, jeśli nie niszczy" - komentuje Vanney (Ibidem: 96). Autorka przypomina, komu przysługuje wolność akademicka i czemu służy:

„Wolność akademicka chroni tych na uniwersytecie, którzy dochodzą wiedzy lub prawdy w zakresie swojej wiedzy fachowej. Niejest to uprawnienie do wyrażania poglądów na dowolny temat lub wjakikolwiek sposób. J ej uzasadnieniem nie jest prawo czy dobro indywidualnego naukowca, ale dobro społeczeństwa, które jest potencjalnym beneficjentem rozwoju wiedzy" (Ibidem: 84).

Tak rozumiana wolność zakłada zarówno możliwość popełnienia błędu, jak i otwartość na weryfikację - a więc naukową drogę do odkrywania intersubiektywnego konsensusu, pojmowanego jako „prawda”. Cenna 
społecznie wiedza to ta, która wskazuje kolejne pytaniai kierunki badań (Ibidem: 94).

J ak zauważa Zbyszko Melosik, warunkiem akademickiej wolności wygłaszania poglądów jest ich ugruntowanie w fachowej wiedzy w dyscyplinie, powiązane z odpowiedzialnością i koniecznym niekiedy samoograniczeniem. Cenę wolności akademickiej stanowi konieczność poddawania się stałemu procesowi recenzowania przez profesjonalistów (Cole 2015; Melosik 2017).

Transparentność, jawność, otwarty dostęp do publikacji naukowych - to zjawiska oczywiście pożądane, ale mogące dawać złudne poczucie możliwości oceny jakości badań przez osoby spoza akademii czy dyscypliny. J akości badań, ich wagi i gruntowności procesu recenzowania nie da się zrozumieć bez znajomości szerokiego kontekstu badanych problemów, a więc bez lat poświęconych na badania w danej dyscyplinie. Harry Collins za wiarygodną wiedzę akademicką uważa jedynie interakcyjną wiedzę ekspercką, która jest wytwarzana w debacie profesjonalistów, w procesie wzajemnego recenzowania. Funkcjonując poza środowiskiem profesjonalistów nikt nie jest w stanie nabyć takiej wiedzy: niewystarczające jest na przykład samodzielne, choćby wnikliwe i wieloletnie, studiowanie prac z danej dyscypliny (Collins 2018).

Podobnie ocena dydaktyki powinna pozostać wewnętrzną sprawą akademii oraz instancji kontrolnych składających się z kompetentnych akademików. Wydaje się, że uczelnie mają wiele narzędzi do uporania się z problematycznymi zajęciami - przegląd sylabusów, koleżeńskie hospitacje (peer review), wspólną pracę nad zajęciami w instytucjach. Wynoszenie sporów poza uczelnię - a więc stwarzanie sytuacji, gdy prezentuje się szerokiej publiczności niepełne informacje bez istotnych kontekstów - nie sprzyja rozwiązaniu konfliktów z pożytkiem merytorycznym i interpersonalnym, prowadzi za to do ich eskalacji i instrumentalnego wykorzystania dla innych, niepowiązanych z istotą sporu celów społecznych. 
Najtrudniejsza do rozważenia wydaje się kwestia relacji akademia świat zewnętrzny, sprowadzająca się w kontekście rozważanych kwestii do pytania, kto, co i wjaki sposób może mówić na uniwersytecie. Przykłady „ograniczeń wolności akademickiej” - zarówno te przytaczane przez Instytut Ordo Iuris, jak i przez aktywistów innych opisywanych w tym tekście inicjatyw - dotyczą bardzo często odwoływania czy blokowania zaproszeń gości spoza uczelni, które zdaniem Stanleya Fisha (2019) w ogóle nie powinno być rozpatrywane jako powiązane z wolnością akademicką.

W tym przypadku „wolność akademicka” oznacza prawo członków wspólnoty uczelnianej (pracowników naukowych i organizacji studenckich) do zapraszania do dyskusji wybranych akademików spoza danego uniwersytetu oraz innych przedstawicieli społeczeństwa, których głos jest ważny ze względu na akademicki cel - rozważeniekonkretnego problemu. Zapraszający muszą spełnić określone wymogi formalne: uzyskać akceptację przełożonych, zapewnić bezpieczeństwo uczestnikom, zaprezentować akademicką ramę spotkania (zajęcia dydaktyczne o celu poznawczym, spotkanie z moderatorem poświęcone określonemu problemowi, debata prezentująca złożoność zagadnienia). Trudno więc uznać wymienione w raporcie Ordo Iuris przyczyny odwołań spotkań przez uczelnie za pretekstualne. Bronić można raczej tezy przeciwnej w przypadku imprez tego typu, ponadprogramowych w stosunku do głównych zadań uczelni, aspekty proceduralne nabywają szczególnego znaczenia.

Istotne w tym kontekście wydają mi się dwie fundamentalne kwestie. Pierwsza związana jest z pytaniem, czy akademickie cele poznawcze mogą być realizowane przy pomocy dopuszczenia do głosu na uczelni pozycji jawnieideologicznych, politycznych i religijnych. Druga dotyczy statusu tego, kto mówi na uczelni - czy jego pozycja jest dobrze rozumiana i komunikowana? Czy zawsze jest to ten, kto mówi „prawdę”, ze względu na miejsce, z którego przemawia? Czy jego opinia uzyskuje uznany status ze względu na przestrzeń, w której jest formułowana? 
J ako osoba prowadząca zajęcia poświęcone problematyce ruchów spolecznych oraz zapraszająca na nie rozmaitych przedstawicieli organizacji ruchów społecznych (między innymi Instytutu Ordo Iuris) stawałam wielokrotnie wobec dylematów związanych z oboma problemami.

Arkadiusz Chrudzimski (2016) w tekście Neutralność światopogladowa dowodzi, że pewne typy dyskursu (ideologiczne, światopoglądowe) są szkodliwe dla instytucji publicznych opartych na racjonalnym poznaniu, w tym uniwersytetów. Trudno odmówić mu racji, gdy myślimy o fundamentach, na których zbudowane są owe instytucje trudno też jednak zaprzeczyć, że ideologiczny, religijny czy czysto praktyczny punkt widzenia może stanowić wiedzę społecznie cenną $\mathrm{w}$ tym znaczeniu, o jakim pisze Vanney: stanowić inspirację do stawiania nowych pytań i powstawania nowych kierunków badań.

Kieruje nas to do pytania drugiego: jaki jest status ideologa zabierającego głos na uniwersytecie na zaproszenie akademickiej wspólnoty? Michał Zabdyr-J amróz (2017), który sądzi, że głosy osób spoza uczelni pomagają uczonym identyfikować istotne społeczne problemy, zastrzega jednak, że gościom nie można oddać pola: ich wypowiedzi powinny odbywać się w formie debat panelowych (które dają możliwość kontrowania poglądów przez innych mówców) lub przybierać ksztalt świadectw (konfrontowanych z innymi, analizowanych), wyraźnie odróżnianych od wykładów.

Pozornie więc kryteria wydają się jasne: na uniwersytecie podmiotami mówiącymi są uczeni (ci, których wypowiedzi poddajemy ocenie wedle kryteriów akademickich), a pozostałe wypowiedzi są przedmiotem analizy, poszerzeniem pola poznania, czasem (to już mniej oczywiste przypadki, które mogą budzić zastrzeżenia) symbolem dobrych wzajemnych stosunków między akademią a inną instytucją, której reprezentanta gości. J est jednak wiele przypadków przenikania się akademii i pola społecznego: wybitni praktycy mogą prowadzić wybrane zajęcia dydaktyczne, naukowcy mogą łączyć badania ze społecznym 
działaniem (są nurty badań zaangażowanych, które mają solidną literaturę przedmiotu), wreszcie akademia i instytucje mogą podejmować wspólne inicjatywy, w których dopiero synergia różnych rodzajów wiedzy daje pożądany efekt. Te przedsięwzięcia są zazwyczaj klarownie komunikowane, jasne są ich cele i charakter udziału stron.

Inaczej może być, gdy na zajęcia zapraszany jest aktywista ruchu religijnego lub ideologicznego lub gdy koło naukowe ogłasza na Facebooku spotkanie otwarte ze znaną działaczką pro-life. W każdym z tych przypadków warto zadbać o wyjaśnienie wszystkim zainteresowanym stronom celu planowanego spotkania, ponieważ większość problemów w przypadku tego typu przedsięwzięć spowodowana jest przez nieporozumienia komunikacyjne.

Choć zawsze starałam się swoim gościom przedstawiać poznawczy cel zajęć, na które ich zapraszałam, niekiedy dostawałam pytania, czy występują w roli „wykładowców”, czy „obiektów badań”. Pierwsza z tych ról odbierana jest jako nobilitująca, druga - jako uprzedmiotawiająca. Nie występują oni jednak w żadnej z tych ról, choć niewątpliwie spotkanie może podlegać analiziei być inspiracją do badań dla studentówi wykładowców, a dla gości do działań. Spotkanie jest przestrzenią, gdzie wspólnie dyskutujemy o problemach naszego świata i poznajemy nawzajem swoje sposoby ich rozumienia. Często nie zgadzamy się, ale rozmawiamy: bezpośrednia komunikacja sprzyja pogłębieniu refleksji. Warunkiem powodzenia jest jednak dobre zrozumienie sytuacji przez wszystkich jej uczestnikówi akceptacja akademickiej ramy.

W przypadku spotkania otwartego z działaczką pro-life, komunikowanego publicznie, zwłaszcza za pomocą mediów elektronicznych, prawdopodobieństwo dekontekstualizacji, omyłkowego zrozumienia intencji, instrumentalnego wykorzystania przez przeciwników i zwolenników ideowych - jest znacznie większe. Dlatego też warto jeszcze dokładniej wyjaśnić cel spotkania i jego kontekst na każdym jego etapie począwszy od zaproszenia, skończywszy na podsumowaniu. J eśli wia- 
domo, że działaczka pro-life zwykła dawać świadectwo, nie zaś problematyzować pole, na którym działa - warto tak to przedstawić. Wtedy problematyzacja należy do zapraszających: być może świadectwo pomoże zauważyć te problemy kobiet w nieplanowanej ciąży, które są pomijane w debacie publicznej? I tu konieczne jest respektowanie ramy akademickiej i reguł przestrzeni, w której odbywa się spotkanie (poznawcze cele, kultura debaty).

Moim zdaniem do reguł tych niemusi należeć wymaganie ideologicznej równowagi podczas debaty - obecność działacza pro-choice na tym samym spotkaniu niekoniecznie sprawi, że zrozumienie problemu przez słuchaczy stanie się pełniejsze. Bardziej prawdopodobne jest, że sprowadzi argumenty stron do tych znanych z wojen kulturowych i obniży wartość poznawczą spotkania. Wystarczająca w takim wypadku wydaje mi się komunikacyjna rzetelność i zastosowanie się do wymogów formalnych danej uczelni, ustanowionych przez jej odpowiednie ciała (w tym na przekład komisje etyczne). Zachowanie tych warunków powinno, jak sądzę, uczynić zbędnymi prawne i regulaminowe próby zarządzania światopoglądową różnorodnością na uniwersytetach.

Literatura

Academic Freedom in the Post-9/11 Era. (2010). (Eds.) Carvalho, E.J ., Downing, D.B. New York: Palgrave Macmillan.

Bromwich, D. (2015). Academic Freedom and Its Opponents. [w:] Who's afraid of academic freedom? (2015). (Eds.) Bilgrami, A.R., Cole, J.R. New York: Columbia University Press, 27-39.

Brońmy Profesor! (2020). https:/ / bronmyprofesor.pl [22.08.2020] Burszta, W. (2013). Kotwice pewności. Wojny kulturowe z popnacjonalizmem $w$ tle. Warszawa: Wydawnictwo Iskry.

Butler, J . (2010). Walczące stowa. Mowa nienawiści i polityka performatywu. Warszawa: Wydawnictwo Krytyki Politycznej. 
Chrudzimski, A. (2016). Neutralność światopoglądowa. Analiza i Egzystencja, 34, 45-69.

Cole, J.R. (2015). Academic Freedom Under Fire. [w:] Who's afraid of academic freedom? (2015). (Eds.) Bilgrami, A.R., Cole, J.R.. New York: Columbia University Press, 40-56.

Collins, H. (2018). Czy wszyscy jesteśmy ekspertami?. Warszawa: Wydawnictwo Naukowe PWN.

Duda, M. (2016). Dogmat plci. Polska wojna z gender. Gdańsk: Wydawnictwo Naukowe Katedra.

Evans, M.S. (2016). Seeking Good Debate. Religion, Science, and Conflict in American Public Life. Oakland: University of California Press. Fish, S. (2019). The First. How to Think About Hate Speech, Campus Speech, Religious Speech, Fake News, Post-Truth, and Donald Trump. New York, London, Toronto, New Delhi: Atria/ One Signal Publishers.

Fish, S. (2016). Winning Arguments. What Works and Doesn't Work in Politics, the Bedroom, the Courtroom, and the Classroom. New York: HarperCollins.

Fish, S. (2014). Versions of Academic Freedom. From Professionalism to Revolution. Chicago, London: The University of Chicago Press.

Free Speech University Rankings 2018 (2018). https:// media.spikedonline.com/ website/ images/ 2019/ 02/ 21153835/ FSUR-PACK2018.pdf [22.08.2020]

Giroux, H.A. (2010). Academic Unfreedom in America. Rethinking the University as a Democratic Public Sphere. [w:] Academic Freedom in the Post-9/11 Era. (Eds.) Carvalho, E., Downing, D. New York: Palgrave Macmillan, 19-40.

Grajewski, A. (2020). Nie chodzi tylko o mnie. Radio Em. https:/ / www. radioem.pl/doc/6121519.Nie-chodzi-tylko-o-mnie [23.01.2020] Groupthink in Science. Greed, Pathological Altruism, Ideology, Competition, and Culture. (2020). (Eds.) Allen, D.A., Howell, J.H. Cham: Springer. 
van Harskamp, A. (2003). Conflicts in Social Science. [w:] Conflicts in Social Science. (Ed.) van Harskamp, A. London- New York: Routledge, 1-21.

Heterodox Academy (b.d.). https:/ / heterodoxacademy.org/ Komitet Kryzysowy Humanistyki Polskiej o inicjatywie min. Jarosława

Gowina i Ordo Iuris dotyczącej wolności słowa na uczelniach (2020). http://kkhp.pl/ 2020/ 01/23/ o-inicjatywie-min-jaroslawa-gowina-i-ordo-iuris/ [16.08.2020]

Koniec autonomii uczelni publicznych $w$ Polsce? Minister Gowin i Ordo Iuris w natarciu (2020). https:/ / www.facebook.com/ notes/ uniwersytet-zaangażowany/ koniec-autonomii-uczelni-publicznych-w-polsce-minister-gowin-i-ordo-luris-w-nata/ 2826497750746509/ [23.08.2020]

Kwak A. (2018). Czy trwałość więzi rodzinnych mimo przemian społecznych? Roczniki Nauk Spolecznych 10(4), 165-171.

Leszczyński, A. (2020). Żłobek jak obóz koncentracyjny. Co mówiła na zajęciach prof. Budzyńska, której broni Gowin. Oko Press. https:// oko.press/ zlobek-jak-oboz-koncentracyjny-co-mowila-na-zajeciach-prof-budzynska-ktorej-broni-gowin/ [20.08.2020]

Lista najważniejszych ograniczeń wolności akademickiej $w$ Polsce (2020). https:// ordoiuris.pl/ node/ 1615 [23.08.2020]

Melosik, Z. (2015). Wolność akademicka. kontakty i rekonstrukcje. Rocznik Lubuski, 41(2), 13-27.

Melosik, Z. (2017). Uniwersytet współczesny i rekonstrukcje wolności akademickiej. Studia Pedagogiczne, 50, 23-36.

Mizielińska, J . (2017). Odmienne czy zwyczajne? Rodziny z wyboru $w$ Polsce. Warszawa: Wydawnictwo Naukowe PWN.

MNiSW przedstawito założenia nowelizacji Konstytucji dla Nauki (2020). https:// www.gov.pl/ web/ nauka/mnisw-przedstawilo-zalozenia-nowelizacji-konstytucji-dla-nauki [20.08.2020]

Murem za Profesorem Aleksandrem Nalaskowskim (2020). https:// muremzaprofesorem.pl [19.08.2020] 
Nelson, C. (2010). No University is an Island. Saving Academic Freedom. New York, London: New York University Press.

Nalaskowski, A. (2019). Wędrowni gwałciciele. Sieci, 34, 108.

Nalaskowski, A. (2020). Wielkie zatrzymanie. Co się stało z ludźmi? Kraków: Biały Kruk.

Omodeo, P.D. (2019). Political Epistemology. The Problem of Ideology in Science Studies. Cham: Springer.

Opinia Krajowej Sekcji Nauki NSZZ „Solidarność” w sprawie projektu ustawy o zmianie ustawy - Prawo o szkolnictwie wyższym i nauce z dnia 28 stycznia 2020 r. (2020). https:// www.solidarnosc.org.pl/ $\mathrm{ksn} / \mathrm{pl} /$ news/261/ [20.08.2020]

Opinia ON ws. projektu nowelizacji ustawy Prawo o szkolnictwie wyższym i nauce dotyczącego ochrony wolności naukowej (2020). http:/ / obywatelenauki.pl/ 2020/ 03/ opinia-on-ws-projektu-nowelizacji-ustawy-prawo-o-szkolnictwie-wyzszym-i-nauce-dotyczacegoochrony-wolnosci-naukowej/ [19.08.2020]

Oświadczenie studentów/ek Uniwersytetu Śląskiego: Chcemy Uniwersytetu wolnego od nienawiści! (2020). https://kph.org.pl/ oswiadczenie-studentow-ek-uniwersytetu-slaskiego-chcemy-uniwersytetu-wolnego-od-nienawisci/ [23.08.2020]

Projekt nowelizacji ustawy Prawo o szkolnictwie wyższym $i$ nauce (2020). https:// ordoiuris.pl/sites/ default/files/inline-files/ Projekt_ nowelizacji_Prawa_o_szkolnictwie_wyzszym.pdf [19.08.2020]

Schulman, S. (2016). Conflict Is Not Abuse. Overstating Harm, Rommunity responsibility, and the Duty of Repair. Vancouver: Arsenal Pulp Press.

Solidarnie z przestuchiwanymi studentkami i studentami Uniwersytetu Śląskiego (2020). https:// naszademokracja.pl/petitions/ solidarnie-z-przesluchiwanymi-studentkami-i-studentami-uniwersytetu-slaskiego [15.08.2020] 
Stanowisko Instytutu na rzecz kultury prawnej Ordo Iuris $w$ sprawie projektu ustawy o zmianie ustawy - Prawo o szkolnictwie wyższym i nauce (wersja z 28.01.2020 r.) (2020). https://ordoiuris.pl/ edukacja/ stanowisko-instytutu-na-rzecz-kultury-prawnejordo-iuris-w-sprawie-projektu-ustawy-o [23.08.2020]

Stanowisko Prezydium KRASP $w$ sprawie projektu ustawy o zmianie ustawy - Prawo o szkolnictwie wyższym i nauce z dnia 28 stycznia 2020 r. (2020). https:// www.krasp.org.pl/ resources/ upload/ dokumenty/Uchwały/dok47_ VII.pdf [22.08.2020]

Stiksma, M. (2020). Understanding the Campus Expression Climate: Fall 2019. Heterodox Academy. https:// heterodoxacademy.org/ wpcontent/ uploads/ 2020/ 07/CES-Fall-2019.pdf [23.08.2020]

Świrek, K. (2013). Trzy końce ideologii - najważniejsze dwudziestowieczne ujęcia problemu. Nauka i Szkolnictwo Wyższe, 41(1), 43-55. Uchwała nr 132/2020 Rady Głównej Nauki i Szkolnictwa Wyższego z dnia 13 lutego 2020 r. w sprawie projektu ustawy o zmianie ustawy - Prawo o szkolnictwie wyższym i nauce z dnia 28 stycznia 2020 r. (2020). http:// www.rgnisw.nauka.gov.pl/ uchwaly/ uchwala-nr-1322020-rady-glownej-nauki-i-szkolnictwa-wyzszego-z-dnia-13-lutego-2020-r-w-sprawie-projektu-ustawy-o-zmianie-ustawy-prawoo-szkolnictwie-wyzszym-i-nauce-z-dnia-28-stycznia-2020-r.html [21.08.2020]

Vanney M.A. (2019). Wolność akademicka $w$ amerykańskim systemie prawnym. Zasady i paradoksy. [w:] Wolność słowa. Współczesne wyzwania $w$ perspektywie prawnoporównawczej. (Red.) Blicharz, G., Delijewski, M. Warszawa: Wydawnictwo Instytutu Wymiaru Sprawiedliwości, 33-102.

Wallach Scott, J . (2019). Knowledge, power, and academic freedom. New York: Columbia University Press.

Who's a fraid of academic freedom? (2015). (Eds.) Bilgrami, A.R., Cole, J.R.. New York: Columbia University Press. 
Williams, J. (2016). Academic Freedom in an Age of Conformity. Confronting the Fear of Knowledge. Basingstoke, New York: Palgrave Macmillan.

Wilson, J.K. (2010). Marketing McCarthyism. The Media's Role in the War on Academic Freedom. [w:] Academic Freedom in the Post9/11 Era. (2010). (Eds.) Carvalho, E.J., Downing, D.B. New York: Palgrave Macmillan, 51-61.

Zabdyr-Jamróz, M. (2017). Czy akademik może mówić, co zechce? O blaskach i cieniach heterodoksyjnej akademii. Nowe Peryferie. https:// nowe-peryferie.pl/index.php/ 2017/ 03/ akademik-mozemowic-zechce-o-blaskach-cieniach-heterodoksyjnej-akademii/ [23.03.2017]

Ziemińska, R. (2013). Dwie koncepcje prawdy i dwie wizjeświata. Roczniki Filozoficzne, 61(3), 29-41.

Zimniak-Hałajko, M. (2019). Przemoc wobec uniwersytetu, uniwersytet wobec przemocy. Zakłócanie wykładów jako praktyka komunikacyjna. [w:] Przemoc w komunikacji. (red.) Bizior, R., Suska, D. Częstochowa: Wydawnictwo Naukowe Uniwersytetu HumanistycznoPrzyrodniczego im. J ana Długosza w Częstochowie, 193-207. 